\title{
Development and Prospect of Intra-Articular Injection in the Treatment of Osteoarthritis: A Review
}

This article was published in the following Dove Press journal:

Journal of Pain Research

\author{
Yin Zhang ${ }^{1,2}$ \\ Xinji Chen' \\ Yu Tong ${ }^{3}$ \\ Junchao Luo $^{3}$ \\ Qing $B i^{1,2}$ \\ 'Department of Orthopedic Surgery, \\ Zhejiang Provincial People's Hospital and \\ People's Hospital of Hangzhou Medical \\ College, Hangzhou, Zhejiang 3100I4, \\ People's Republic of China; ${ }^{2}$ The First \\ Affiliated Hospital of Bengbu Medical \\ University, Bengbu, Anhui 233004, \\ People's Republic of China; ${ }^{3}$ The Second \\ Affiliated Hospital and Yuying Children's \\ Hospital of Wenzhou Medical University, \\ Wenzhou, Zhejiang 325000, People's \\ Republic of China
}

Correspondence: Qing Bi

Department of Orthopedic Surgery,

Zhejiang Provincial People's Hospital, No.

I58 Shangtang Road, Hangzhou, Zhejiang,

People's Republic of China

Email bqzjsrmyy@163.com

\begin{abstract}
Osteoarthritis (OA) is a common degenerative disease that affects the vast majority of the elderly and may eventually embark on the road of the total knee arthroplasty (TKA), although controversy still exists in the medical community about the best therapies for osteoarthritis. Compared with physical therapy, oral analgesics and other non-operative treatments, intra-articular injection is more safe and effective. Moreover, intra-articular injection is much less invasive and has fewer adverse reactions than surgical treatment. This article reviews mechanism, benefits and adverse reactions of corticosteroids (CS), hyaluronic acid (HA), platelet-rich plasma (PRP), mesenchymal stem cell (MSCs), stromal vascular fraction (SVF) and other new therapies (for example: gene therapy). The application prospect of intra-articular injection was analyzed according to the recent progress in drug research.
\end{abstract}

Keywords: osteoarthritis, intra-articular injection, treatment, prospect, review

\section{Introduction}

Articular cartilage is a particular type of tissue which is found in common joints such as the knee, hip, shoulder and ankle. ${ }^{1}$ Acute trauma, repeated stress and impaired vascular supply can lead to cartilage damage. These lesions will cause osteoarthritis (OA), which is characterized by swelling, deformity and joint stiffness. $^{2}$

Osteoarthritis is a degenerative joint disease, the main feature is the slow progressive destruction of articular cartilage with the degeneration of ligaments and menisci. ${ }^{3}$ The pathogenesis involves many complex mechanisms, including genetic, mechanical, metabolic, inflammatory factors and so on. Up to now, the evidence has revealed that inflammatory factors, abnormal apoptosis of chondrocytes and degradation of extracellular matrix are related to the pathogenesis of OA. In particular, the abnormal expression of inflammatory factors such as tumor necrosis factor (TNF-a), interleukin-1 (IL-1) and interleukin-6 (IL-6) will lead to the increase of chondrocyte apoptosis and the degradation of extracellular matrix, which eventually results in the occurrence of osteoarthritis. ${ }^{4,5} \mathrm{OA}$ is a global disease problem, more than $50 \%$ of patients who over the age of 60 are affected. To date, about 300 million people are living with OA, and 242 million people are suffering pains from hip/knee osteoarthritis., 6 With the growing number of the elderly and obese, the incidence of OA is still rising. ${ }^{8}$ 
As for therapy, the choice of the treatment for $\mathrm{OA}$ is conservative or surgical therapies according to the patient's age, the severity of symptoms and the type of lesion. According to the guidelines of the Osteoarthritis Society International (OARSI) and National Institute for Health and Care Excellence (NICE), conservative therapy should be regarded as the first choice for the treatment of OA. ${ }^{9,10}$ Conservative therapies include physical therapy based on weight loss and exercise, and drug therapy based on nonsteroidal anti-inflammatory drugs (NSAIDs) and prostacyclin. However, the effect of single drug appears to be unconspicuous in terms of improving pain and function in patients with OA. ${ }^{11}$ Systemic drugs such as NSAIDs may have no obvious therapeutic effect, and even cause a variety of adverse reactions such as cardiovascular, stomach and kidney, thus limiting their use in the elderly with OA.

For surgical therapies, arthroscopic debridement with bone marrow stimulation (BMS), autologous or allogeneic osteochondral transplantation, autologous chondrocyte transplantation and autologous periosteal bone-graft have become conventional methods for the treatment of OA. The study showed that arthroscopic debridement with BMS has the advantages of less trauma and simple operation, and can improve the clinical effects to a certain degree. However, the repaired cartilage is fibrocartilage, the wear resistance of fibrocartilage is not as good as the normal cartilage. The long-term therapeutic effect is still non-ideal after a period of time. ${ }^{12}$ Autologous chondrocyte implantation (ACI) is suitable for large osteochondral defects left after the failure of the first treatment. But this method is time-consuming, expensive, and the clinical effect is not accurate. Periosteal bone-graft is also suitable for patients with large osteochondral lesions. The advantages include that the periosteum has a certain ability of cartilage metaplasia, the periosteum of the bone-graft can be closely combined with bone, and the repaired problem of delamination between cartilage and subchondral bone was solved. Nevertheless, the periosteal layer may be over proliferated and need secondary arthroscopic repair, which increases the trauma caused by the operation. Therefore, intra-articular injection with appropriate therapeutic dose may be a better mode of drug administration. ${ }^{13}$ It is a promising therapy which can play key roles in the treatment of OA. Because it can effectively improve the effect of local treatment, and has reliable safety which can reduce the occurrence of systemic adverse reactions. ${ }^{14}$

In this review, we focused on the therapies of osteoarthritis by intra-articular injection which include corticosteroids (CS), hyaluronic acid (HA), platelet-rich plasma (PRP), mesenchymal stem cell (MSCs), stromal vascular fraction (SVF) and other new therapies. The latest research progress related to these therapies, the mechanism of function and adverse effects of them were summarized and concluded. According to the results, the application prospect of intra-articular injection was analyzed in the treatment of osteoarthritis.

\section{Corticosteroids}

Although osteoarthritis is a degenerative joint disease, at some phases, low-grade inflammation will occur which provides a practical and reliable theoretical basis for the application of intra-articular anti-inflammatory drugs. As common local anti-inflammatory drugs, corticosteroids fight the inflammatory process of $\mathrm{OA}$ by altering the immune function of $\mathrm{T}$ and $\mathrm{B}$ cells. ${ }^{15}$ Compared with natural corticosteroids, synthetic corticosteroids obviously have stronger antiinflammatory effects, which can be mainly divided into two forms: crystalline and non-crystalline. At present, crystalline triamcinolone and non-crystalline methylprednisolone acetate are used most commonly. ${ }^{13}$ The injection process usually requires a combination of local anesthetics for intra-articular injection of corticosteroids (IACS).

Triamcinolone acetonide (TA) is less water soluble than methylprednisolone and is the most difficult to dissolve among injectable corticosteroids, so triamcinolone acetonide is a better choice for the diabetic who are worried about rising blood glucose after injection. ${ }^{16}$ It takes three weeks for triamcinolone acetonide (TA) to be completely absorbed from the joint and can be detected in plasma after six weeks. Because triamcinolone acetonide absorbs faster, it stays in plasma for longer. ${ }^{17}$ The mean residence time (MRT) of TA is 2.5-4.3 days. Generally, MRT will change with the variation of product dose. Triamcinolone acetonide extended release (FX006) can keep the drug concentration in the joint within a certain range for a long time, and MRT can be as long as 19 days. ${ }^{18}$ In a double-blind, randomized, parallel-group, Phase II clinical study, it was found that intra-articular injection of triamcinolone acetonide extended release can relieve symptoms of OA pains with minimal blood glucose disruption. ${ }^{19}$ Betamethasone, as a combination of betamethasone disodium phosphate and betamethasone acetate, MRT was only 2.8 days. ${ }^{18}$ Methylprednisolone acetate (MPA) can significantly relieve pain in patients in the early stage. According to related studies, the efficacy of intra-articular injection of MPA peaked at 2 weeks after injection and the effect lasted until 24 weeks. ${ }^{20}$ In a recent study, it was found that the effect of 
methylprednisolone acetate may last for three months or more. ${ }^{21}$ Information about common intra-articular corticosteroids is summarized in Table 1.

Studies have confirmed that the intra-articular corticosteroids can significantly relieve the clinical symptoms of patients with early OA. Nonetheless, the relief of this symptom is short-lived and no other benefits are seen half a year later. $^{22}$ According to the retrospective literature, most patients with osteoarthritis showed a mild to moderate improvement in function within 6 weeks after corticosteroids injection, but the patient's symptoms did not improve significantly after this period of time. ${ }^{23}$ The specific contraindications and adverse reactions are shown in Table 2. The long-term use of corticosteroids can increase oxidative stress and change gene expressions of chondrocyte. It will lead to chondrotoxicity and other adverse reactions, and accelerates the progress of osteoarthritis. ${ }^{24}$ The latest study found that there is a certain causal relationship between high dose and long-term use of corticosteroids and the development of chondraltoxicity. ${ }^{25}$ Therefore, in order to relieve symptoms in the short term, intra-articular corticosteroids should not be injected for symptomatic joints more than 4 times a year. ${ }^{26}$ Many studies confirmed that intra-articular injection of corticosteroids only offers a mild and temporary pain-relieving effect, and surgeons must doubt the sustainability and development of this treatment in future medicine.

\section{Hyaluronic Acid (HA)}

In addition to intra-articular injection of corticosteroids, hyaluronic acid (HA) is also commonly used in the treatment of osteoarthritis. Its essence is glycosaminoglycan, which is composed of $\beta$-glucuronide and $\beta$-acetylglucosamine produced by B-type synoviocytes, chondrocytes and fibroblasts. ${ }^{27}$ Figure 1 shows the structure formula of HA. As the main component of intra-articular synovial fluid, HA is present in the upper layer
Table 2 Indications, Contraindications and Adverse Reactions of the Intra-Articular Injection of Corticosteroid, and the Methods to Reduce the Incidence of Adverse Reactions

\begin{tabular}{|l|l|l|}
\hline Indications & Contraindications & $\begin{array}{l}\text { Adverse } \\
\text { Reactions }\end{array}$ \\
\hline Osteoarthritis & $\begin{array}{l}\text { Intra-articular or osteochondral } \\
\text { fracture at the injection site }\end{array}$ & $\begin{array}{l}\text { Injection site } \\
\text { pain and local } \\
\text { swelling }\end{array}$ \\
\hline $\begin{array}{l}\text { Rheumatoid } \\
\text { arthritis }\end{array}$ & Uncontrolled coagulopathy & $\begin{array}{l}\text { Atrophic } \\
\text { changes of skin }\end{array}$ \\
\hline $\begin{array}{l}\text { Traumatic } \\
\text { arthritis }\end{array}$ & $\begin{array}{l}\text { Severe joint destruction (eg, } \\
\text { Charcot joint) and skin } \\
\text { breakdown }\end{array}$ & Septic arthritis \\
\hline $\begin{array}{l}\text { Shoulder } \\
\text { periarthritis }\end{array}$ & $\begin{array}{l}\text { Local infection: septic arthritis, } \\
\text { periarticular sepsis and } \\
\text { bacteremia }\end{array}$ & Chondrotoxicity \\
\hline $\begin{array}{l}\text { Crystalline } \\
\text { arthropathies }\end{array}$ & Hypersensitivity to the injection & $\begin{array}{l}\text { Anaphylactic } \\
\text { reactions }\end{array}$ \\
\hline $\begin{array}{l}\text { Seronegative } \\
\text { arthropathies }\end{array}$ & Osteomyelitis & $\begin{array}{l}\text { Soft tissue } \\
\text { calcinosis }\end{array}$ \\
\hline $\begin{array}{l}\text { Mixed } \\
\text { connective } \\
\text { tissue disease }\end{array}$ & Joint prosthesis & $\begin{array}{l}\text { Crystal-induced } \\
\text { erythema }\end{array}$ \\
\hline
\end{tabular}

of articular cartilage 1-2 microns. ${ }^{28}$ Compared with normal knees containing 2.5 to $4 \mathrm{mg} / \mathrm{mL}$ of HA, the knee of patients with osteoarthritis has a decrease of 1 to $2 \mathrm{mg} / \mathrm{mL}$ due to reduced production of $\mathrm{HA}$ and increased self-degradation and clearance, with a reduction of up to $50 \% .{ }^{27}$

Since it was approved by Food and Durg Administration (FDA) for the treatment of OA in the United States in 1997, hyaluronic acid has been widely used. ${ }^{29}$ Table 3 shows the different brand name approved by FDA that contains HA. It was found that intra-articular injection of HA in the treatment of osteoarthritis may mainly rely on two mechanisms:

Table I Information About Intra-Articular Injection of Corticosteroids

\begin{tabular}{|c|c|c|c|c|c|}
\hline Agent & $\begin{array}{l}\text { Anti-Inflammatory } \\
\text { Potency }\end{array}$ & Action Time & $\begin{array}{l}\text { Dose: From Small } \\
\text { Joint to Large Joint }\end{array}$ & Serum Half-Life & Fluorinated \\
\hline Hydrocortisone acetate & I & $S$ & $10-25(\mathrm{mg})$ & $2 \mathrm{~h}$ & No \\
\hline Triamcinolone acetate & 5 & 1 & $2.5-15(\mathrm{mg})$ & $88 \mathrm{~min}$ & Yes \\
\hline Triamcinolone hexacetonide & 5 & 1 & $2-20(\mathrm{mg})$ & $88 \mathrm{~min}$ & Yes \\
\hline Methylprednisone acetate & 5 & 1 & $4-80(\mathrm{mg})$ & $18-26 \mathrm{~h}$ & No \\
\hline Dexamethasone & 25 & L & $0.8-4(\mathrm{mg})$ & $36-54 \mathrm{~h}$ & Yes \\
\hline Betamethasone acetate & 25 & L & $0.25-2(\mathrm{~mL})$ & $6.5 \mathrm{~h}$ & Yes \\
\hline Betamethasone sodium phosphate & 25 & L & $0.25-2(\mathrm{~mL})$ & $6.5 \mathrm{~h}$ & Yes \\
\hline
\end{tabular}

Abbreviations: S, short $=8-12 \mathrm{~h}$ biologic half-life; I, intermediate $=12-36 \mathrm{~h}$ biologic half-life; L, long $=36-72 \mathrm{~h}$ biologic half-life. 


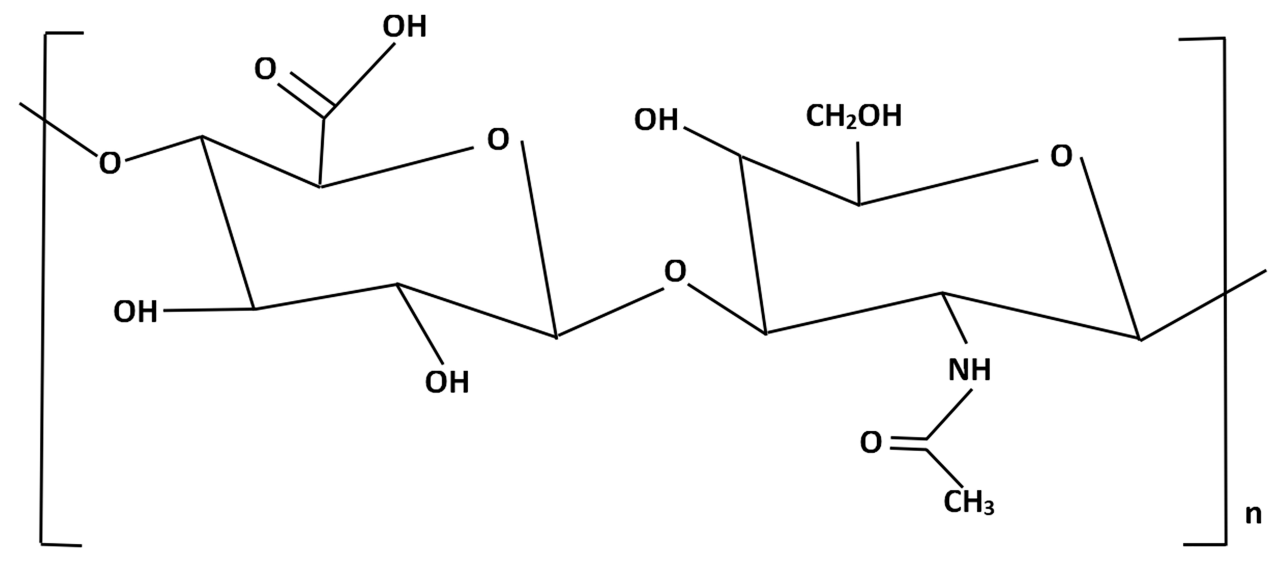

Figure I The structure formula of hyaluronic acid.

first, as a supplement to intra-articular mechanical viscosity, it can play the role of joint protection such as lubrication, shock absorption and friction reduction; ${ }^{30}$ Second, the homeostasis of joint is reconstructed by guiding the secretion of endogenous HA. ${ }^{31}$ Because HA not only has the function of structural, but also plays the role of signal molecule. In the process of interaction with receptors on the surface of different cells such as B-type synoviocytes and chondrocytes, it plays an important role in regulating cellular proliferation, differentiation and migration. These effects that have an influence on extracellular matrix, which not only promotes the synthesis of endogenous HA, but also reduces the markers of cartilage destruction. Meanwhile, it has anti-inflammatory effects on inflammatory mediators, such as reducing the secretion of prostaglandins, leukotrienes, IL-1 and IL-6. ${ }^{32}$ In addition, hyaluronic acid (HA) as a natural glycosaminoglycan with viscoelastic properties, is an important component of the extracellular matrix of articular cartilage. It is also a great guarantee for the biomechanical integrity of healthy cartilage. ${ }^{33}$

The clinical trial study of using HA to treat osteoarthritis has become a hot topic for many scholars. Trueba Davalillo et al compared the clinical efficacy of intra-

Table 3 Information About Drugs Which Contain Hyaluronic Acid

\begin{tabular}{|l|l|l|}
\hline Product & Dosage & Frequency \\
\hline Hyalgan & $2.0 \mathrm{~mL}$ & Once a week for 5 weeks \\
Supartz & $2.5 \mathrm{~mL}$ & Once a week for 5 weeks \\
Supartz FX & $2.5 \mathrm{~mL}$ & Once a week for 5 weeks \\
Orthovisc & $2.0 \mathrm{~mL}$ & Once a week for 3 to 4 weeks \\
Euflexxa & $2.0 \mathrm{~mL}$ & Once a week for 3 to 5 weeks \\
Hylan G-F 20 & $2.0 \mathrm{~mL}$ & Once a week for 3 weeks \\
\hline
\end{tabular}

articular injection of $\mathrm{HA}$ and betamethasone in a randomized controlled trial involved 200 patients. After one-year follow-up, the Visual Analogue Score (VAS) (Figure 2) of intra-articular injection of HA was significantly lower than that of betamethasone except for the third month. It reported that the improvement of Western Ontario and McMaster University Osteoarthritis Index (WOMAC) score (Table 4) by intra-articular injection of HA was significantly better than that of intra-articular injection of betamethasone. ${ }^{34}$

According to the relevant experimental data, different molecular weight (MW) of HA has different effects on patients. Some experts believe that the molecular weight of HA may affect clinical efficacy and safety. The low molecular weight seems to be less effective than high molecular weight. ${ }^{35}$ Due to the heterogeneity of this study, however, the results are not supported by other studies. In a clinical study of hybrid (low and high molecular weight) and high molecular weight hyaluronic acid in the treatment of osteoarthritis in obese patients. It was found that the therapeutic effect of hybrid hyaluronic acid was better than high molecular weight hyaluronic acid. The study still proposed the combination of the antiinflammatory action of low molecular weight HA on chondrocytes and the biomechanical role of high molecular weight HA might be the reason for this result. ${ }^{36}$ The research on the contraindications of intra-articular injection of HA is not specific, and most scholars think that it is similar to the contraindication of intra-articular injection of corticosteroids. In 2019, Gualdi et al found that patients with scleroderma should be regarded as a contraindication for injection of HA, because HA has a pro-inflammatory effect which leads to the migration of keratinocytes and worsening skin ulcers. ${ }^{37}$ 


\begin{tabular}{|l|l|l|l|l|l|l|l|l|l|l|}
0 & 1 & 2 & 3 & 4 & 5 & 6 & 7 & 8 & 9 & 10
\end{tabular}

No pain

Worst possible

Pain

Figure 2 Visual Analog Scale (VAS), a common tool for measuring pain.

Nevertheless, the efficacy of HA in the treatment of OA has not been confirmed. By the end of 2014, American Academy of Orthopaedic Surgeons (AAOS) had not found evidence that HA could be listed as an indicator for the treatment of knee osteoarthritis. ${ }^{6}$ In 2015 , the evidence found in 14 meta-analysis studies proved the feasibility of hyaluronic acid in patients with knee osteoarthritis. But unfortunately, the control in the meta-analysis studies was different, resulting in a significant reduction in the credibility of the evidence. ${ }^{38} \mathrm{~A}$ recent systematic review and meta-analysis study showed intra-articular hyaluronic acid provided significant pain relief compared to saline for patients with early-moderate knee OA. Meanwhile, it did not increase the risk of treatment-related adverse events for up to 6 months. However, patients with end-stage disease had a lower level of pain relief, and the risk of treatment-related adverse events was significantly higher

Table 4 Western Ontario and McMaster University Osteoarthritis Index (WOMAC) Questionnaire

\begin{tabular}{|l|l|l|}
\hline Pain & Stiffness & Physical Function \\
\hline Walking & $\begin{array}{l}\text { The severity of your } \\
\text { stiffness after wakening up } \\
\text { in the morning }\end{array}$ & $\begin{array}{l}\text { Descending stairs; } \\
\text { Ascending stairs; } \\
\text { Rising from sitting; }\end{array}$ \\
\hline $\begin{array}{l}\text { Up and } \\
\text { down } \\
\text { the } \\
\text { stairs }\end{array}$ & $\begin{array}{l}\text { Standing; } \\
\text { Bending to floor; } \\
\text { Walking on flat; } \\
\text { Guring } \\
\text { sleep } \\
\text { Stiffness after sitting, lying in/out of car; } \\
\text { or resting later in the day }\end{array}$ & $\begin{array}{l}\text { Shopping; } \\
\text { Putting on socks; } \\
\text { Rising from bed; } \\
\text { Taking off socks; }\end{array}$ \\
\hline $\begin{array}{l}\text { Sitting or } \\
\text { lying }\end{array}$ & & $\begin{array}{l}\text { Lying in bed; } \\
\text { Getting in/out the bath; } \\
\text { Sitting; } \\
\text { Getting on/off toilet; }\end{array}$ \\
\hline $\begin{array}{l}\text { Standing } \\
\text { upright }\end{array}$ & & $\begin{array}{l}\text { Heavy domestic duties; } \\
\text { Light domestic duties }\end{array}$ \\
\hline
\end{tabular}

than saline. ${ }^{39}$ In a low-risk trial, it was found that the frequency of intra-articular injection of HA may increase from once in one cycle to fifth in four cycles. ${ }^{40}$ Therefore, intra-articular injection of HA may cause more local adverse reactions than intra-articular injection of corticosteroids, such as self-limited synovitis, joint bleeding and muscle pain, which may be due to the higher frequency of intra-articular injection. ${ }^{41}$ It has become the consensus for most doctors to discourage the use of hyaluronic acid in every patient with osteoarthritis. ${ }^{9}$

\section{Platelet-Rich Plasma (PRP)}

Platelet-rich plasma (PRP) is a new product of regenerative medicine which has attracted more and more attention. However, the earliest clinical application of PRP occurred in 1987, it was used for blood loss after open heart surgery. ${ }^{42}$ To date, it has been proven to delay aging and improve cell vitality. Therefore, it was widely used in plastic surgery. ${ }^{43}$

In essence, platelet-rich plasma is a type of autologous plasma. Compared with normal plasma, the platelet concentration of PRP is higher, which usually contains 150,000 to 300,000 platelets per microliter. ${ }^{44}$ At present, the common cognition is that the normal platelet concentration is 2 to 8 times before it is used as autoserum. ${ }^{45}$ The specific process of PRP preparation is shown in Figure 3. The platelet in PRP contains a large number of growth factors and antiinflammatory cytokines. When platelet is activated, insulinlike growth factor-1 (IGF-1), insulin-like growth factor-2 (IGF-2), vascular endothelial growth factor (VEGF), transforming growth factor- $\beta$ (TGF- $\beta$ ), fibroblast growth factor (FGF) and platelet-derived growth factor (PDGF) will be released at the site of healing. ${ }^{46,47}$ These factors can improve the growth of mesenchymal stem cells (MSCs) and autologous chondrocytes. Meanwhile, it also increases the components of extracellular matrix such as proteoglycans and type I and II collagen. ${ }^{48,49}$ After intra-articular injection of PRP, the growth factors such as FGF- $\beta$, VEGF, PDGF-BB and IGF1 increased at different time. This phenomenon may 


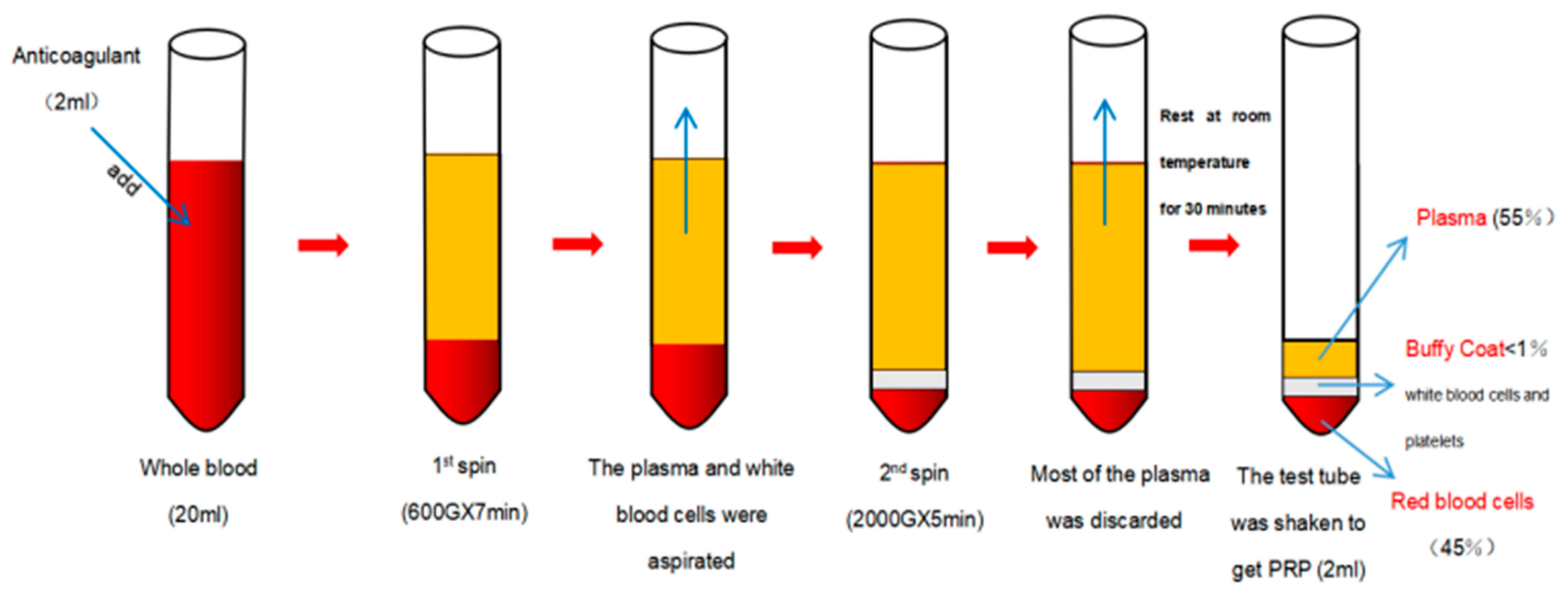

Figure 3 The preparation process of platelet-rich plasma (PRP).

suggest that PRP is not a single increase of the growth factors, but stimulates the increase of growth factors by activating the intrinsic pathway of growth factors. ${ }^{50}$ It also can decrease and decompose the concentration of proinflammatory cytokines through inhibiting the activation of the nuclear factor kappa-light-chain-enhancer (NF-KB) by interleukin-1 (IL-1), which can reduce the inflammatory effect in the process of OA. ${ }^{51}$ In addition, the study proposed that transforming growth factor- $\beta$ (TGF- $\beta$ ) can increase the mitotic effect of osteoblasts. ${ }^{52}$

Same as hyaluronic acid, PRP still lacks high-quality clinical data to prove the reliability of efficacy. Although PRP has been used as a routine therapy in clinic, this indication has not been approved by FDA, and most insurance companies have not covered it in the coverage. The research about the clinical efficacy of PRP has never stopped in recent years. This was confirmed by Lin's randomized clinical trial of PRP and HA compared with the control group (normal saline) in the treatment of mild to moderate knee osteoarthritis. He found that PRP could provide a significant improvement in clinical function for over 1 year, and the most significant improvement was at the 6th month. ${ }^{53}$ Furthermore, some meta-analysis studies confirmed that PRP has a good clinical effect and better healing for young patients with early OA. ${ }^{54}$ In 2019 , Guillibert et al treated and followed up 57 patients with osteoarthritis. He found that a good clinical effect was obtained by a single injection of very pure PRP, and the symptoms of $84.2 \%$ of the patients were relieved. The WOMAC Score, Knee Injury and Osteoarthritis Outcome Score (KOOS) and Medical Outcomes Study Short Form-36 items (SF-36) questionnaires were significantly improved in first, third and sixth month. No adverse reactions occurred. ${ }^{55}$ Jihad et al proposed the platelet lysates can be used for the treatment of early and intermediate knee osteoarthrosis. The specific procedure was that the growth factors were released by platelets in vitro and injected them directly in the injured joint. They performed intra-articular injection of platelet lysates in 48 patients with degenerative changes in the joint of grade I or II on the Kellgren scale and followed up for one year. Finally, it was found that the patient had a significant improvement in the 5 aspects: symptoms, stiffness, pain, daily living and sport. This new idea may be a promising direction for the development of PRP in the future. ${ }^{56}$

In summary, platelet-rich plasma has considerable potential value as a new medical product which is very promising. Due to the lack of standardized factors such as speed and time of centrifugation in the preparation of PRP, however, variants are rich in white blood cells or without white blood cells may be produced. ${ }^{57}$ And adverse reactions include the pain of injection site, joint stiffness, dizziness, headache, nausea and tachycardia. Therefore, there must be additional standardized and high-quality clinical trial to support the application of PRP in clinic.

\section{Mesenchymal Stem Cell (MSC)}

Mesenchymal stem cell (MSC) has shown a good application prospect in relieving pain and cartilage regeneration. Extensive clinical studies confirmed that it is a safe and effective therapy, some scholars even tried to reverse the development of cartilage lesions by cell regeneration. ${ }^{58}$ Mesenchymal stem cell is a group of different kinds of stromal cell. It can be isolated from bone marrow, adipose tissue, synovium and other connective tissues. In 1999, 
Pittenger isolated MSC from bone marrow for the first time. He proposed that MSC has the potential ability of differentiating into adipocytes, osteoblasts and chondrocytes. ${ }^{59}$ With more in-depth research, it was found that MSC can also be isolated from placenta, umbilical cord blood, umbilical cord perivascular cells, cartilage, fat pad and skeletal muscle. Information on MSC from different sources is shown in Table 5. Bone marrow mesenchymal stem cells (BMSCs) and adipose-derived mesenchymal stem cells (AMSCs) are most commonly used in clinic which gradually developed into a conventional therapy for OA. ${ }^{69}$

The mechanism of action of MSC is not completely clear at present; however, the release of chemical mediators is considered to be an important factor of the in vivo mechanism of BMSCs, which is mainly divided into two categories: immunity or anti-inflammation and tissue repair or regeneration. ${ }^{70}$ Many studied confirmed that BMSCs can improve the secretion of growth factors and the management of tissue environment. ${ }^{71}$ These effects can benefit the process of cartilage repair and regeneration, such as cell migration, cell proliferation, cell differentiation and matrix synthesis. Through the adjustment of transforming growth factor- $\beta$ (TGF- $\beta$ ), vascular endothelial growth factor (VEGF), matrix metalloproteinases (MMPs), tissue inhibitors (TIMPs) and other growth factors. It can not only reduce the damage of tissues and cells, but also stimulate the proliferation of stem cells and promote the repair of stromal vessels. ${ }^{72}$ The immunomodulatory function and anti-inflammatory effect are

Table 5 A Summary of the Information About MSC Acquired from Several Common Sources

\begin{tabular}{|c|c|c|c|c|}
\hline $\begin{array}{l}\text { Cell } \\
\text { Source }\end{array}$ & Positive Characterization & Advantages & Disadvantages & $\begin{array}{l}\text { Latest Studies } \\
\text { Related to OA }\end{array}$ \\
\hline $\begin{array}{l}\text { Bone } \\
\text { marrow }\end{array}$ & $\begin{array}{l}\text { CDI05,CD73, } \\
\text { CD90, } \\
\text { CD27I,CDI46, } \\
\text { low-affinity nerve } \\
\text { growth factor } \\
\text { receptor (LNGFR) }\end{array}$ & $\begin{array}{l}\text { (i) High chance of differentiat- } \\
\text { ing into cartilage } \\
\text { (ii) Rich in sources }\end{array}$ & $\begin{array}{l}\text { (i) High variability } \\
\text { (ii) The number and quality of cells } \\
\text { decrease with age }\end{array}$ & $\begin{array}{l}\text { Doyle }^{60} \text { et al } \\
(2020)\end{array}$ \\
\hline $\begin{array}{l}\text { Adipose } \\
\text { tissue }\end{array}$ & CD73,CD90,CDI05 & $\begin{array}{l}\text { (i) Low donor site morbidity } \\
\text { (ii) Rich in sources } \\
\text { (iii) Easy to get }\end{array}$ & $\begin{array}{l}\text { (i) The number and quality of cells } \\
\text { decrease with age } \\
\text { (ii) Low chance of differentiating } \\
\text { into cartilage }\end{array}$ & $\begin{array}{l}\text { Woo }{ }^{61} \text { et al } \\
(2020)\end{array}$ \\
\hline $\begin{array}{l}\text { Synovial } \\
\text { membrane }\end{array}$ & $\begin{array}{l}\text { CD44,CD73,CD90, } \\
\text { CD105,CD166, CD27I }\end{array}$ & $\begin{array}{l}\text { (i) High chance of differentiat- } \\
\text { ing into cartilage } \\
\text { (ii) Low osteogenic potential }\end{array}$ & (i) Low numbers & $\begin{array}{l}\text { Gale }^{62} \text { et al } \\
(2019)\end{array}$ \\
\hline Placenta & $\begin{array}{l}\text { CD90,CD 105,CDI66, } \\
\text { CD49e,SH3,SH4, HLA-ABC }\end{array}$ & $\begin{array}{l}\text { (i) High chance of differentiat- } \\
\text { ing into cartilage }\end{array}$ & $\begin{array}{l}\text { (i) Hard to get } \\
\text { (ii) Low numbers }\end{array}$ & $\begin{array}{l}\text { Khalifeh Soltani }{ }^{63} \\
\text { et al } \\
(2019)\end{array}$ \\
\hline $\begin{array}{l}\text { Umbilical } \\
\text { cord } \\
\text { blood }\end{array}$ & $\begin{array}{l}\text { CD 13,CD29,CD49e, CD54, } \\
\text { CD90 a-smooth muscle } \\
\text { actin }\end{array}$ & $\begin{array}{l}\text { (i) Easy to get } \\
\text { (ii) Unlimited numbers }\end{array}$ & (i) High variability & $\begin{array}{l}J^{\text {Jeon }}{ }^{64} \text { et al } \\
(2020)\end{array}$ \\
\hline $\begin{array}{l}\text { Umbilical } \\
\text { cord } \\
\text { perivascular } \\
\text { cells }\end{array}$ & CD 105,CD73,CD90, CD44 & $\begin{array}{l}\text { (i) Easy to get } \\
\text { (ii) Unlimited numbers }\end{array}$ & (i) High variability & $\begin{array}{l}\text { Klontzas }^{65} \text { et al } \\
(2015)\end{array}$ \\
\hline Cartilage & CD49e,Notch I, CD90, STRO-I & $\begin{array}{l}\text { (i) High chance of differentiat- } \\
\text { ing into cartilage }\end{array}$ & $\begin{array}{l}\text { (i) High donor site morbidity } \\
\text { (ii) Low number }\end{array}$ & $\begin{array}{l}\mathrm{Hu}^{66} \text { et al } \\
(2019)\end{array}$ \\
\hline Fat pad & $\begin{array}{l}\text { CDI3,CD44,CD90, CDI05, } \\
\text { CD29 }\end{array}$ & $\begin{array}{l}\text { (i) Rich in sources } \\
\text { (ii) Easy to get }\end{array}$ & $\begin{array}{l}\text { (i) Low chance of differentiating } \\
\text { into cartilage }\end{array}$ & $\begin{array}{l}\text { Bravo }^{67} \text { et al } \\
(2018)\end{array}$ \\
\hline $\begin{array}{l}\text { Skeletal } \\
\text { muscle }\end{array}$ & $\mathrm{NG} 2, \mathrm{CD} \mid 46$ & $\begin{array}{l}\text { (i) Easy to get } \\
\text { (ii) Unlimited numbers. }\end{array}$ & (i) High variability & $\begin{array}{l}\text { Camernik }{ }^{68} \text { et al } \\
(2020)\end{array}$ \\
\hline
\end{tabular}


embodied in the adjustment of interleukin, TNF- $\alpha$, interferon- $\gamma$ (IFN- $\gamma$ ) and other factors. Under the action of these factors, bone marrow mesenchymal stem cells secrete a variety of anti-inflammatory cytokines to feedback to various types of immune cells and play the role of immunity and anti-inflammation. ${ }^{73}$ The results of a study involving 86 patients have proved that BMSCs can reduce the expression of TNF- $\alpha$ and IL- 6 in osteoarthritis and increase antiinflammatory effect. ${ }^{74}$ Recently, Maximed et al proposed a new viewpoint on the mechanism of action of MSC. They believed that the transforming growth factor- $\beta$ induced gene (TGFBI) is a protective factor of articular cartilage. $^{75}$

In addition to the study of the mechanism, the clinical efficacy of BMSCs never stops. Vangsness and his colleagues followed up 55 patients from 7 different institutions for 2 years. They found that the OA pain was significantly relieved in patients with single injection of BMSCs. The subchondral bone sclerosis and osteophyte formation were also reduced, and the results of magnetic resonance imaging (MRI) also showed the progress of OA slowed down. ${ }^{76}$ Mahasen et al reported that expanded autologous bone marrow mesenchymal stem cells (BM-MSCs) were used to treat 13 patients with moderate and severe knee osteoarthritis. After 24 months follow-up, there were no adverse events. Meanwhile, normalized KOOS improved, and the mean thickness of knee cartilage measured by MRI also promoted. ${ }^{77}$ And a study included 1069 knee joints, Migliorini et al found the patients with intraarticular injection of bone marrow mesenchymal stem cells. After 12 months, WOMAC Function Scores, Lequesne Index Scores, Knee Injury and Osteoarthritis Outcome Score (KOOS), and the quality of life (QOL) of patients were significantly improved. ${ }^{78}$ Compared with other treatments of cartilage regeneration, BMSCs are autologous which avoids the risk of autoimmune responses. Meanwhile, the number and purity of BMSCs are high, and it is easier to differentiate into articular tissue. ${ }^{79}$ Furthermore, the approach of culture and expansion in vitro can provide the opportunity of adding extra drugs and increase the repair potential of chondrocytes.

Adipose-derived mesenchymal stem cells (AMSCs) can also be used in the treatment of OA. Adipose tissue is a more easily available source of stem cells. Compared with BMSCs, AMSCs are easier to cultivate and have stronger ability of cell growth and proliferation. It is also an advantage of AMSCs that telomerase is less affected by age than BMSCs. ${ }^{80}$ In 1972 , AMSCs were first described as adipocyte precursor cell by
Frohlich. ${ }^{81}$ Further studies found that AMSCs have the ability to differentiate into mesoderm-derived cells such as adipocytes, osteocytes and chondrocytes. Through a vitro study, Ceserani et al found high concentrations of AMSCs may inhibit the inflammatory effect of macrophages. ${ }^{82}$ The clinical studies have also shown the therapeutic effect of AMSCs. In the study of adipose-derived mesenchymal stem cells (AMSCs) (dosage: $2 \times 10^{6}$ cells, $10 \times 10^{6}$ cells, $50 \times 10^{6}$ cells). ${ }^{83}$ Pers et al found that the dosage of $2 \times 10^{6}$ cells was the best in relief of function and pain. He proposed that the regulation of congenital and acquired immunity may be the mechanism of AMSCs. ${ }^{84}$ Russo et al also confirmed that AMSCs are not only a safe therapy, but also found a significant improvement in VAS score, International Knee Documentation Committee (IKDC) score and Tegner-Lysholm (TL) score during oneyear follow-up. ${ }^{85}$ Hudetz et al studied the results of the injection of adipose-derived mesenchymal stem cells (AMSCs) from clinic and imaging, respectively. It was found that the VAS score was significantly decreased, while imaging showed a significant increase in the glycosaminoglycan (GAG) content from articular cartilage. ${ }^{86}$

Some studies have demonstrated the safety and tolerance of mesenchymal stem cells, no adverse events (AEs) have been reported. The incidence of adverse reactions is only $3.1 \%$, such as pain and swelling, ${ }^{63,87,88}$ and the carcinogenicity of mesenchymal stem cell in theory has not been confirmed. ${ }^{89}$ However, the malignant transformation of cells is still a potential risk of stem cell therapy. According to the results of the system review in 2017, more than $1 / 3$ of the researches cannot accurately describe their methods of evaluating safety. ${ }^{90}$ Furthermore, current studies have not reached a consensus on the best source, isolation, recognition and culture conditions of MSC. Both BMSCs and AMSCs are invasive and cause iatrogenic injury to patients. Large-scale and long-term clinical trials are still needed to popularize and improve intra-articular injection of mesenchymal stem cells, and make it become a conventional method for clinical treatment of osteoarthritis.

\section{Stromal Vascular Fraction (SVF)}

Although studies have confirmed the safety and efficacy of Adipose tissue-derived stem cells (ADSCs) and mesenchymal stem cells (MSCs) in the treatment of OA. ${ }^{91}$ It may take several weeks to isolate, culture and amplify cells in specialized laboratory. ${ }^{92}$ At present, it seems that autologous stromal vascular fraction (SVF) is a more effective method. The adipose tissue from liposuction is digested by collagenase, and the floating adipocytes and liquefied fat are removed by 
centrifugation. Finally, the cell pellet left at the bottom of the tube, called SVF. ${ }^{93}$ The cell of SVF includes ADSCs, macrophages, blood cells, pericytes, fibroblasts, vesselforming cells (such as endothelial and smooth muscle cells) and their progenitors. ${ }^{94}$ Due to different extraction methods, the content of ADSCs in different SVF from less than $1 \%$ to more than $15 \%$. Among the current studies, eight studies reported liposuction on the day before surgery, ${ }^{95-102}$ and four studies reported liposuction on the same day. ${ }^{87,103-}$ ${ }^{105}$ Compared with ADSCs and MSCs, SVF saves several weeks of cell culture and proliferation, and is more efficient.

Studies have shown that stromal vascular fraction (SVF) can not be dependent on adipose tissue sources or donors. It can play an anti-inflammatory effect on chondrocytes and synoviocytes through the release of anti-inflammatory molecules such as interleukin-1 receptor antagonist (IL-1Ra), indoleamine-2, 3-dioxygenase, transforming growth factor$\beta$ and prostaglandin E2. ${ }^{106}$ The study also suggests that the cells in SVF seem to be able to perceive the local environment of $\mathrm{OA}$ and respond to it accordingly. On the other hand, the regulating effect of SVF on preadipocytes, vascular adventitia cells, macrophages, red blood cells, fibroblasts and regulatory $\mathrm{T}$ cells can promote tissue renewal. ${ }^{107}$

In 2011, autologous SVF composed of heterogeneous cells released by enzymatic hydrolysis of adipose tissue, which contains adipose stromal cells, hematopoietic stem cells, endothelial cells, fibroblasts, lymphocytes, erythrocytes, pericytes and monocytes/macrophages was used in OA patients in combination with hyaluronic acid (HA). After 3-month follow up, the study found that the VAS score decreased and the patient's range of motion improved. Meanwhile, magnetic resonance imaging showed cartilage regeneration. ${ }^{108}$ Since then, more and more clinical studies have been used to explore the therapeutic efficacy of SVF for the treatment of OA. In 2013, Pak et al reported a retrospective cohort study involving 91 patients with OA. The patients were injected with autologous SVF and PRP percutaneously. After three-months follow up, it was found that the VAS score was significantly improved, and there were no serious side effects or development of tumor. ${ }^{105}$ In a clinical study of 18 patients aged between 18 and 75 . Jo et al found the dose of SVF seemed to be associated with pain, stiffness and function. After high-dose $\left(1.0 \times 10^{8}\right.$ cells) SVF injection, it was observed that the WOMAC Function Scores of the patients with a mean reduction of $39 \%$ after 6 months. Magnetic resonance imaging showed cartilage regeneration. Glossy white matrix and hyaline-like cartilage were found in arthroscopy, and well integrated with subchondral bone. ${ }^{109}$

There is still lack of clinical trials with large samples and comparison with other treatments such as platelet-rich plasma or arthroscopic debridement. Many studies support intra-articular injection of SVF to alleviate the symptoms of osteoarthritis (OA) and promote cartilage regeneration. These studies showed the symptoms of OA were improved one month to two years after SVF injection. The quality of life of patients was improved, and the risk of adverse reactions was not increased. Only a very small number of patients reported slight swelling and pain in the first few days, and there were no serious complications at the donor site. ${ }^{100,103}$ SVF can be employed in a point of care setting for different indications and is currently being widely used all over the world with reports of various degrees of success. SVF is easy to prepare and rich in sources (such as adipose tissue in the abdomen or buttocks), without a series of complicated steps such as cell culture and proliferation. These advantages suggest that SVF may be a safe and effective minimally invasive method for the treatment of OA and has a good application prospect.

\section{Other Therapies}

The imbalance between catabolic and anabolic factors may appear in the development of OA. This theory gives scholars new expectations for the use of biological agents in the treatment of OA. ${ }^{110}$ It has been confirmed that IL-1 $\beta$ can lead to cartilage degeneration and the destruction of joint tissue by affecting the catabolism of inflammatory factors. ${ }^{111}$ Some scholars believe that IL-1 $\beta$ can induce the dedifferentiation of chondrocytes and directly lead to the erosion process of OA in vivo. ${ }^{112,113}$ It seems that contraposing IL-1 $\beta$ can inhibit the process of OA. However, the results of clinical trials of IL-1 $\beta$ antagonist anakinra are not satisfactory. A randomized, multicentre, double-blind, placebo-controlled trial showed that anakinra did not significantly alleviate the symptoms of OA. ${ }^{114}$ Tumor necrosis factor (TNF) is another important factor in the development of $\mathrm{OA}$, and its essence is a proinflammatory cytokine, which is related to the loss of knee cartilage. ${ }^{115}$ At present, the most frequently used TNF inhibitors are infliximab and etanercept. Although some studies have confirmed the initial tolerability of infliximab, intra-articular injection of infliximab to treat $\mathrm{OA}$ is still in the early stage of exploration. In a clinical controlled trial of HA and etanercept, it was found that the VAS score of patients injected with etanercept was better 
than that of patients injected with $\mathrm{HA}$ in the first 1-2 weeks, but the difference between two drugs gradually shrunk after the fourth week. ${ }^{116}$

The development of gene therapy for cartilage preservation and regeneration has increased the hope of the treatment for OA. Generally speaking, gene therapy can be divided into viral-based gene therapy and non-viral gene therapy. To date, adenovirus-mediated gene therapy is a common method. But inefficient gene transduction is the main obstacle for using widely. It has been confirmed that the conjugation of a-10 integrin antibody and the capsid of helper-dependent adenoviral-vector can not only lead to effective chondrocyte infection, but also detarget other types of cells at the same time. ${ }^{117}$ There are still some problems with adenovirus vector in the treatment of OA, such as immunogenicity, insertional mutagenesis, sustainability of transgene expression and so on. ${ }^{118}$ Non-viral gene therapy does not have the related problems of adenovirus-mediated gene therapy. Nevertheless, it is difficult for chondrocytes to enter the avascular cartilage, the dense collagen matrix also hinders the absorption of drugs. Therefore, how to make the drug play a therapeutic role in the joint is still a problem to be solved.

Botulinum toxin A (BTA) is a neurotoxin which was produced by the bacterium Clostridium botulinum. BTA is mainly used in the treatment of neuromuscular disorders. Many animal experimental studies have found that intraarticular injection of BTA can relieve the pain of OA to a certain extent. ${ }^{119}$ Although the exact mechanism of action is not clear, BTA inhibits the release of neurotransmitters to decrease central sensitization may be an important factor. ${ }^{120}$ Moreover, the study found that BTA can also inhibit the release of mediators involved in nociception, such as substance $\mathrm{P}$, calcitonin gene-related peptide and glutamate. ${ }^{121}$ In a randomized controlled trial of botulinum toxin A, HA, and saline. The injection of botulinum toxin type A or hyaluronic acid significantly relieved pain and improved knee function. Meanwhile, it was suggested that botulinum toxin type A plus therapeutic exercise seems to get better results. ${ }^{122}$

\section{Discussion}

Osteoarthritis (OA) manifests the loss of joint structure and function caused by the unbalanced dynamic equilibrium between destruction and repair of articular tissue, which may result in clinical symptoms of pain and disability. To date, the challenges of OA therapy research include complex interactions of various pathological mechanisms, the presence of various phenotypes in the $\mathrm{OA}$ pathogenic spectrum and difference in the rate of progression of disease among different populations. ${ }^{123,124}$ Especially for the elderly, the safety of drugs is particularly important because of long-term treatment.

Intra-articular injection therapies can maximize therapeutic effects locally and have potential safety. Meanwhile, the probability of systemic exposure lowered, and the incidence of adverse reactions is also reduced. At present, several intra-articular drugs have been used to treat OA which include corticosteroids, hyaluronic acid, platelet-rich plasma, mesenchymal stem cell, stromal vascular fraction and other drugs. However, there are few randomised controlled trials that compare these drugs in the treatment of $\mathrm{OA}$.

In 2013, Rodriguez-Merchan confirmed that intraarticular injections of HA provide more lasting relief than intra-articular injection of corticosteroids. He found corticosteroids showed significant clinical effect only in the first 4 weeks. However, the effect provided by HA lasted for 26 weeks. ${ }^{125}$ The latest research also showed that intra-articular injection of HA had fewer side effects and more significant relief of symptom than intra-articular injection of corticosteroids for patients with early osteoarthritis. ${ }^{126}$ In 2016, a randomized controlled trial of the intra-articular injection of PRP and corticosteroid showed that PRP could alleviate the clinical symptoms and improve the joint function of patients than the injection of corticosteroids. ${ }^{127}$ A meta-analysis study which contained 1543 patients proposed that PRP was superior to HA in pain control. The beneficial effect may last as long as a year, especially in patients with mild OA. ${ }^{128}$ In clinical trials of regenerative medical products, HA is the most common drug in the control group. Aurelio et al divided 30 patients into experimental group and control group, and injected MSCs and HA, respectively. After one-year follow-up study, the joint function of patients injected with MSCs was significantly improved than the injection of HA. By quantitative magnetic resonance imaging T2 mapping, the cartilage quality improved significantly in MSC-treated patients. ${ }^{129}$ A recent double-blind randomized self-controlled trial of HA and SVF. It was found that intra-articular injection of SVF significantly improved VAS, WOMAC Function Scores and the knee range of motion (ROM) within 12 months than intra-articular injection of HA. Meanwhile, compared with HA, whole-organ magnetic 
resonance imaging score (WORMS) and magnetic resonance observation of cartilage repair tissue (MOCART) score of SVF was significantly improved. ${ }^{130}$

In this review, we have synthesized the current drugs for the intra-articular injection in the treatment of osteoarthritis (OA). Although HA and corticosteroids have always been standard intra-articular treatments. The patients with advanced osteoarthritis, we do not recommend intraarticular injection with HA and corticosteroids. Because there may be no obvious improvement in symptoms, and the increase in the number of injections will lead to adverse reactions. In recent years, the products of regenerative medicine include platelet-rich plasma (PRP), mesenchymal stem cells (MSCs) and stromal vascular fraction (SVF) are becoming increasingly prevalent in the treatment of osteoarthritis. Meanwhile, most of the studies about these drugs have also achieved satisfactory clinical results. However, it is too early to draw conclusions on the ultimate effectiveness and safety of these regenerative medical products in terms of cartilage regeneration. More patients and high-level radiological and histological evidences are required to prove the reasonable use of PRP, MSCs, SVF in osteoarthritis.

\section{Conclusion}

In conclusion, intra-articular therapy can provide good local therapeutic effect and minimize adverse reactions for patients, especially some regenerative medical products. It is an effective and promising treatment option to solve the pain of patients by minimally invasive way, which has a good application prospect and is worthy of further research and exploration.

\section{Author Contributions}

All authors made substantial contributions to conception and design, acquisition of data, or analysis and interpretation of data; took part in drafting the article or revising it critically for important intellectual content; gave final approval of the version to be published; and agree to be accountable for all aspects of the work.

\section{Disclosure}

The content of this manuscript reflects the opinion of the author. All the authors state that there are no possible conflicts of interest in the manuscript.

\section{References}

1. Sophia F, Bedi A, Rodeao SA. The basic science of articular cartilage: structure, composition, and function. Sports Health. 2009;1(6):461-468. doi:10.1177/1941738109350438

2. Bhosale AM, Richardson JB. Articular cartilage: structure, injuries and review of management. $\mathrm{Br}$ Med Bull. 2008;87(1):77-95. doi:10.1097/JSA.0000000000000090

3. Sun HB. Mechanical loading, cartilage degradation and arthritis. Ann NY Acad Sci. 2010;1211:37-50. doi:10.1111/j.1749-6632. 2010.05808.x

4. Wang Y, Fan X, Xing L, et al. Wnt signaling: a promising target for osteoarthritis therapy. Cell Commun Signal. 2019;17(1):97. doi:10.1186/s12964-019-0411-x

5. Woodell-May JE, Sommerfeld SD. Role of inflammation and the immune system in the progression of osteoarthritis. J Orthop Res. 2020;38(2):253-257. doi:10.1002/jor.24457

6. GBD 2017. Disease and Injury Incidence and Prevalence Collaborators. Global, regional, and national incidence, prevalence, and years lived with disability for 354 diseases and injuries for 195 countries and territories, 1990-2017: a systematic analysis for the Global Burden of Disease Study 2017. Lancet. 2018;392 (10159):1789-1858. doi:10.1016/S0140-6736(18)32279-7/.

7. Global Burden of Disease Study 2013 Collaborators. Global, regional, and national incidence, prevalence, and years lived with disability for 301 acute and chronic diseases and injuries in 188 countries, 1990-2013: a systematic analysis for the Global Burden of Disease Study 2013. Lancet. 2015;386(9995):743-800. doi:10.1016/S0140-6736(15)60692-4.

8. Neogi T, Zhang Y. Epidemiology of osteoarthritis. Rheum Dis Clin North Am. 2013;39(1):1-19. doi:10.1016/j.rdc.2012.10.004

9. Bannuru RR, Osani MC, Vaysbrot EE, et al. OARSI guidelines for the non-surgical management of knee, hip, and polyarticular osteoarthritis. Osteoarthritis Cartilage. 2019;27(11):1578-1589. doi:10.1016/j.joca.2019.06.011

10. Centre NCG. National Institute for Health and Clinical Excellence: Guidance. Osteoarthritis: Care and Management in Adults. London: National Institute for Health and Care Excellence (UK); 2014:2.

11. Leopoldino AO, Machado GC, Ferreira PH, et al. Paracetamol versus placebo for knee and hip osteoarthritis. Cochrane Database Syst Rev. 2019;2:Cd013273. doi:10.1002/14651858. CD013273

12. Desando G, Bartolotti I, Vannini F, et al. Repair potential of matrix-induced bone marrow aspirate concentrate and matrix-induced autologous chondrocyte implantation for talar osteochondral repair: patterns of some catabolic, inflammatory, and pain mediators. Cartilage. 2017;8(1):50-60. doi:10.1177/ 1947603516642573

13. Jones IA, Togashi R, Wilson ML, et al. Intra-articular treatment options for knee osteoarthritis. Nat Rev Rheumatol. 2019;15 (2):77-90. doi:10.1038/s41584-018-0123-4

14. Oo WM, Yu SP, Daniel MS, et al. Disease-modifying drugs in osteoarthritis: current understanding and future therapeutics. Expert Opin Emerg Drugs. 2018;23(4):331-347. doi:10.1080/ 14728214.2018.1547706

15. Jüni $\mathrm{P}$, Hari R, Rutjes $\mathrm{AW}$, et al. Intra-articular corticosteroid for knee osteoarthritis. Cochrane Database Syst Rev. 2015;22(10): CD005328. doi:10.1002/14651858

16. Levy DM, Petersen KA, Scalley Vaught M, et al. Injections for knee osteoarthritis: corticosteroids, viscosupplementation, platelet-rich plasma, and autologous stem cells. Arthroscopy. 2018;34 (5):1730-1743. doi:10.1016/j.arthro.2018.02.022 
17. Caldwell JR. Intra-articular corticosteroids. Guide to selection and indications for use. Drugs. 1996;52(4):507-514. doi:10.21 65/00003495-199652040-00004

18. Oo WM, Liu X, Hunter DJ. Pharmacodynamics, efficacy, safety and administration of intra-articular therapies for knee osteoarthritis. Expert Opin Drug Metab Toxicol. 2019;15(12):1021-1032. doi:10.1080/17425255.2019.1691997

19. Russell SJ, Sala R, Conaghan PG, et al. Triamcinolone acetonide extended-release in patients with osteoarthritis and type 2 diabetes: a randomized, phase 2 study. Rheumatology (Oxford). 2018;57 (12):2235-2241. doi:10.1093/rheumatology/key265

20. Buyuk AF, Kilinc E, Camurcu IY, et al. Compared efficacy of intra-articular injection of methylprednisolone and triamcinolone. Acta Ortop Bras. 2017;25(5):206-208. doi:10.1590/1413-785220172 505172581

21. Leighton R, Akermark C, Therrien R, et al. NASHA hyaluronic acid vs methylprednisolone for knee osteoarthritis: a prospective, multi-centre, randomized, non-inferiority trial. Osteoarthritis Cartilage. 2014;22(1):17-25. doi:10.1016/j.joca.2013.10.009

22. da Costa BR, Hari R, Jüni P. Intra-articular corticosteroids for osteoarthritis of the knee. JAMA. 2016;316(24):2671-2672. doi:10.1001/jama.2016.17565

23. Arroll B, Goodyear-Smith F. Corticosteroid injections for osteoarthritis of the knee: meta-analysis. BMJ. 2004;328(7444):869. doi:10.1136/bmj.38039.573970.7C

24. Suntiparpluacha M, Tammachote N, Tammachote R. Triamcinolone acetonide reduces viability, induces oxidative stress, and alters gene expressions of human chondrocytes. Eur Rev Med Pharmacol Sci. 2016;20(23):4985-4992.

25. Wernecke C, Braun HJ, Dragoo JL. The effect of intra-articular corticosteroids on articular cartilage: a systematic review. Orthop $J$ Sports Med. 2015;3(5):2325967115581163. doi:10.1177/23259 67115581163

26. Wehling P, Evans C, Wehling $\mathrm{J}$, et al. Effectiveness of intra-articular therapies in osteoarthritis: a literature review. Ther Adv Musculoskelet Dis. 2017;9(8):183-196. doi:10.1177/ 1759720X17712695

27. Bert JM, Bert TM. Nonoperative treatment of unicompartmental arthritis: from bracing to injection. Clin Sports Med. 2014;33 (1):1-10. doi:10.1016/j.csm.2013.08.002

28. Cheng OT, Souzdalnitski D, Vrooman B, et al. Evidence-based knee injections for the management of arthritis. Pain Med. 2012;13(6):740-753. doi:10.1111/j.1526-4637.2012.01394.x

29. Conduah AH, Baker CL, Baker CL. Managing joint pain in osteoarthritis: safety and efficacy of Hylan G-F 20. J Pain Res. 2009;2:87-98. doi:10.2147/jpr.s4732

30. Hochberg MC, Altman RD, April KT, et al. American College of Rheumatology 2012 recommendations for the use of nonpharmacologic and pharmacologic therapies in osteoarthritis of the hand, hip, and knee. Arthritis Care Res (Hoboken). 2012;64(4):465-474. doi:10.1002/acr.21596

31. McAlindon TE, Bannuru RR, Sullivan MC, et al. OARSI guidelines for the non-surgical management of knee osteoarthritis. Osteoarthritis Cartilage. 2014;22(3):363-388. doi:10.1016/j. joca.2014.01.003

32. Altman RD, Manjoo A, Fierlinger A, et al. The mechanism of action for hyaluronic acid treatment in the osteoarthritic knee: a systematic review. BMC Musculoskelet Disord. 2015;16:321. doi:10.1186/s12891-015-0775-z

33. Abate M, Salini V. Safety and tolerability of intra-articular hyaluronic acid (Sinovial ${ }^{\circledR} /$ GELSYN-3tm) injections in the treatment of knee osteoarthritis. J Biol Regul Homeost Agents. 2017;31 (4):1139-1145.
34. Trueba Davalillo CA, Trueba Vasavilbaso C, Navarrete Alvarez JM, et al. Clinical efficacy of intra-articular injections in knee osteoarthritis: a prospective randomized study comparing hyaluronic acid and betamethasone. Open Access Rheumatol Res Rev. 2015;7:9-18. doi:10.2147/OARRR.S74553

35. Lo GH, LaValley M, McAlindon T, et al. Intra-articular hyaluronic acid in treatment of knee osteoarthritis: a meta-analysis. JAMA. 2003;290(23):3115-3121. doi:10.1001/jama.290.23.3115

36. Papalia R, Russo F, Torre G, et al. Hybrid hyaluronic acid versus high molecular weight hyaluronic acid for the treatment of osteoarthritis in obese patients. J Biol Regul Homeost Agents. 2017;31(4 Suppl 2):103-109.

37. Gualdi G, Monari P, Cammalleri D, et al. Hyaluronic acid-based products are strictly contraindicated in scleroderma-related skin ulcers. Wounds. 2019;31(3):81-84.

38. Campbell KA, Erickson BJ, Saltzman BM, et al. Is local viscosupplementation injection clinically superior to other therapies in the treatment of osteoarthritis of the knee: a systematic review of overlapping meta-analyses. Arthroscopy. 2015;31(10):2036-2045. doi:10.1016/j.arthro.2015.03.030

39. Nicholls M, Shaw P, Niazi F, et al. The impact of excluding patients with end-stage knee disease in intra-articular hyaluronic acid trials: a systematic review and meta-analysis. Adv Ther. 2019;36 (1):147-161. doi:10.1007/s12325-018-0847-1

40. Richette $\mathrm{P}$, Chevalier $\mathrm{X}$, Ea $\mathrm{HK}$, et al. Hyaluronan for knee osteoarthritis: an updated meta-analysis of trials with low risk of bias. RMD Open. 2015;1(1):e000071. doi:10.1136/rmdopen-2015000071

41. He WW, Kuang MJ, Zhao J, et al. Efficacy and safety of intraarticular hyaluronic acid and corticosteroid for knee osteoarthritis: a meta-analysis. Int $J$ Surg. 2017;39:95-103. doi:10.1016/j. ijsu.2017.01.087

42. Tietze DC, Geissler K, Borchers J. The effects of platelet-rich plasma in the treatment of large-joint osteoarthritis: a systematic review. Phys Sportsmed. 2014;42(2):27-37. doi:10.3810/psm. 2014.05.2055

43. Frautschi RS, Hashem AM, Halasa B, et al. Current evidence for clinical efficacy of platelet rich plasma in aesthetic surgery: a systematic review. Aesthet Surg J. 2017;37(3):353-362. doi:10. 1093/asj/sjw178

44. Pourcho AM, Smith J, Wisniewski SJ, et al. Intraarticular platelet-rich plasma injection in the treatment of knee osteoarthritis: review and recommendations. Am J Phys Med Rehabil. 2014;93(11 Suppl 3): S108-21. doi:10.1097/PHM.0000000000000115

45. Richards MM, Maxwell JS, Weng L, et al. Intra-articular treatment of knee osteoarthritis: from anti-inflammatories to products of regenerative medicine. Phys Sportsmed. 2016;44(2):101-108. doi:10.1080/00913847.2016.1168272

46. Getgood A, Henson F, Brooks R, et al. Platelet-rich plasma activation in combination with biphasic osteochondral scaffolds-conditions for maximal growth factor production. Knee Surg Sports Traumatol Arthrosc. 2011;19(11):1942-1947. doi:10.1007/s00167-011-1456-6

47. Bendinelli P, Matteucci E, Dogliotti G, et al. Molecular basis of anti-inflammatory action of platelet-rich plasma on human chondrocytes: mechanisms of NF- $\kappa \mathrm{B}$ inhibition via HGF. J Cell Physiol. 2010;225(3):757-766. doi:10.1002/jcp.22274

48. Fortier LA, Barker JU, Strauss EJ, et al. The role of growth factors in cartilage repair. Clin Orthop Relat Res. 2011;469 (10):2706-2715. doi:10.1007/s11999-011-1857-3

49. Schmidt MB, Chen EH, Lynch SE. A review of the effects of insulin-like growth factor and platelet derived growth factor on in vivo cartilage healing and repair. Osteoarthritis Cartilage. 2006;14(5):403-412. doi:10.1016/j.joca.2005.10.011 
50. Wasterlain AS, Braun HJ, Harris AH, et al. The systemic effects of platelet-rich plasma injection. Am $J$ Sports Med. 2013;41 (1):186-193. doi:10.1177/0363546512466383

51. van Buul GM, Koevoet WLM, Kops N, et al. Platelet-rich plasma releasate inhibits inflammatory processes in osteoarthritic chondrocytes. Am J Sports Med. 2011;39(11):2362-2370. doi:10. 1177/0363546511419278

52. Halpern B, Chaudhury S, Rodeo SA, et al. Clinical and MRI outcomes after platelet-rich plasma treatment for knee osteoarthritis. Clin J Sport Med. 2013;23(3):238-239. doi:10.1097/JSM.0b013e31827c3846

53. Lin $\mathrm{KY}$, Yang $\mathrm{CC}$, Hsu $\mathrm{CJ}$, et al. Intra-articular injection of platelet-rich plasma is superior to hyaluronic acid or saline solution in the treatment of mild to moderate knee osteoarthritis: a randomized, double-blind, triple-parallel, placebo-controlled clinical trial Arthroscopy. 2019;35(1):106-117. doi:10.1016/j.arthro.2018.06.035

54. Laver L, Marom N, Dnyanesh L, et al. PRP for degenerative cartilage disease: a systematic review of clinical studies. Cartilage. 2017;8(4):341-364. doi:10.1177/1947603516670709

55. Guillibert C, Charpin C, Raffray M, et al. Single injection of high volume of autologous pure PRP provides a significant improvement in knee osteoarthritis: a prospective routine care study. Int $J \mathrm{Mol}$ Sci. 2019;20:6. doi:10.3390/ijms20061327

56. Al-Ajlouni J, Awidi A, Samara O, et al. Safety and efficacy of autologous intra-articular platelet lysates in early and intermediate knee osteoarthrosis in humans: a prospective open-label study. Clin J Sport Med. 2015;25(6):524-528. doi:10.1097/JSM.0000000000000166

57. Khoshbin A, Leroux $\mathrm{T}$, Wasserstein $\mathrm{D}$, et al. The efficacy of platelet-rich plasma in the treatment of symptomatic knee osteoarthritis: a systematic review with quantitative synthesis. Arthroscopy. 2013;29(12):2037-2048. doi:10.1016/j.arthro.2013.09.006

58. Squillaro T, Peluso G, Galderisi U. Clinical trials with mesenchymal stem cells: an update. Cell Transplant. 2016;25(5):829-848. doi:10.3727/096368915X689622

59. Pittenger MF, Mackay AM, Beck SC, et al. Multilineage potential of adult human mesenchymal stem cells. Science. 1999;284 (5411):143-147. doi:10.1126/science.284.5411.143

60. Doyle EC, Wragg NM, Wilson SL. Intraarticular injection of bone marrow-derived mesenchymal stem cells enhances regeneration in knee osteoarthritis. Knee Surg Sports Traumatol Arthrosc. 2020;31. doi:10.1007/s00167-020-05859-z

61. Woo CH, Kim HK, Jung GY, et al. Small extracellular vesicles from human adipose-derived stem cells attenuate cartilage degeneration. $J$ Extracell Vesicles. 2020;9(1):1735249. doi:10. 1080/20013078.2020.1735249

62. Gale AL, Mammone RM, Dodson ME, et al. The effect of hypoxia on chondrogenesis of equine synovial membrane-derived and bone marrow-derived mesenchymal stem cells. BMC Vet Res. 2019;15 (1):201. doi:10.1186/s12917-019-1954-1

63. Khalifeh Soltani S, Forogh B, Ahmadbeigi N, et al. Safety and efficacy of allogenic placental mesenchymal stem cells for treating knee osteoarthritis: a pilot study. Cytotherapy. 2019;21(1):54-63. doi:10.1016/j.jcyt.2018.11.003

64. Jeon HJ, Yoon KA, An ES, et al. Therapeutic effects of human umbilical cord blood-derived mesenchymal stem cells combined with cartilage acellular matrix mediated via bone morphogenic Protein 6 in a rabbit model of articular cruciate ligament transection. Stem Cell Rev Rep. 2020;16(3):596-611. doi:10.1007/s12015-020-09958-9

65. Klontzas ME, Kenanidis EI, Heliotis M, et al. Bone and cartilage regeneration with the use of umbilical cord mesenchymal stem cells. Expert Opin Biol Ther. 2015;15(11):1541-1552. doi:10. 1517/14712598.2015.1068755

66. $\mathrm{Hu} \mathrm{N}$, Gao Y, Jayasuriya CT, et al. Chondrogenic induction of human osteoarthritic cartilage-derived mesenchymal stem cells activates mineralization and hypertrophic and osteogenic gene expression through a mechanomiR. Arthritis Res Ther. 2019;21 (1):167. doi:10.1186/s13075-019-1949-0
67. Bravo B, Argüello JM, Gortazar AR, et al. Modulation of gene expression in infrapatellar fat pad-derived mesenchymal stem cells in osteoarthritis. Cartilage. 2018;9(1):55-62. doi:10.1177/ 1947603516686144

68. Čamernik K, Mihelič A, Mihalič R, et al. Comprehensive analysis of skeletal muscle- and bone-derived mesenchymal stem/stromal cells in patients with osteoarthritis and femoral neck fracture. Stem Cell Res Ther. 2020;11(1):146. doi:10.1186/s13287-020-01657-z

69. Moroni L, Fornasari PM. Human mesenchymal stem cells: a bank perspective on the isolation, characterization and potential of alternative sources for the regeneration of musculoskeletal tissues. J Cell Physiol. 2013;228(4):680-687. doi:10.1002/jcp.24223

70. Galipeau J, Krampera M. The challenge of defining mesenchymal stromal cell potency assays and their potential use as release criteria. Cytotherapy. 2015;17(2):125-127. doi:10.1016/j.jcyt.2014.12.008

71. Meirelles Lda S, Fontes AM, Covas DT, et al. Mechanisms involved in the therapeutic properties of mesenchymal stem cells. Cytokine Growth Factor Rev. 2009;20:419-427. doi:10. 1016/j.cytogfr.2009.10.002

72. Shabbir A, Zisa D, Suzuki G, et al. Heart failure therapy mediated by the trophic activities of bone marrow mesenchymal stem cells: a noninvasive therapeutic regimen. Am J Physiol Heart Circ Physiol. 2009;296:H1888-1897. doi:10.1152/ajpheart.00186.2009

73. Uccelli A, Moretta L, Pistoia V. Mesenchymal stem cells in health and disease. Nat Rev Immunol. 2008;8(9):726-736. doi:10.1038/ nri2395

74. Li J, Shao Q, Zhu X, et al. Efficacy of autologous bone marrow mesenchymal stem cells in the treatment of knee osteoarthritis and their effects on the expression of serum TNF- $\alpha$ and IL-6. J Musculoskelet Neuronal Interact. 2020;20(1):128-135.

75. Ruiz M, Toupet K, Maumus M, et al. TGFBI secreted by mesenchymal stem cells ameliorates osteoarthritis and is detected in extracellular vesicles. Biomaterials. 2020;226:119544. doi:10.1016/j. biomaterials.2019.119544

76. Vangsness CT, Farr J, Boyd J, et al. Adult human mesenchymal stem cells delivered via intra-articular injection to the knee following partial medial meniscectomy: a randomized, double-blind, controlled study. J Bone Joint Surg Am. 2014;96(2):90-98. doi:10.2106/JBJS.M.00058

77. Al-Najar M, Khalil H, Al-Ajlouni J, et al. Intra-articular injection of expanded autologous bone marrow mesenchymal cells in moderate and severe knee osteoarthritis is safe: a Phase I/II study. J Orthop Surg Res. 2017;12(1):190. doi:10.1186/s13018-017-0689-6

78. Migliorini F, Rath B, Colarossi G, et al. Improved outcomes after mesenchymal stem cells injections for knee osteoarthritis: results at 12-months follow-up: a systematic review of the literature. Arch Orthop Trauma Surg. 2019:27. doi:10.1007/s00402-019-03267-8.

79. Kreja L, Ignatius A, Fekete N, et al. GMP-compliant isolation and large-scale expansion of bone marrow-derived MSC. PLoS One. 2012;7(8):e43255. doi:10.1371/journal.pone.0043255

80. Mirsaidi A, Kleinhans KN, Rimann M, et al. Telomere length, telomerase activity and osteogenic differentiation are maintained in adipose-derived stromal cells from senile osteoporotic SAMP6 mice. J Tissue Eng Regen Med. 2012;6(5):378-390. doi:10.1002/ term. 440

81. Frohlich J, Vost A, Hollenberg CH. Organ culture of rat white adipose tissue. Biochim Biophys Acta. 1972;280(4):579-587. doi:10.1016/0005-2760(72)90138-5

82. Ceserani V, Ferri A, Berenzi A, et al. Angiogenic and anti-inflammatory properties of micro-fragmented fat tissue and its derived mesenchymal stromal cells. Vasc Cell. 2016;8:3. doi:10.1186/s13221-016-0037-3

83. Pers YM, Rackwitz L, Ferreira R, et al. Adipose mesenchymal stromal cell-based therapy for severe osteoarthritis of the knee: a Phase I dose-escalation trial. Stem Cells Transl Med. 2016;5 (7):847-856. doi:10.5966/sctm.2015-0245 
84. Pers YM, Quentin J, Feirreira R, et al. Injection of adipose-derived stromal cells in the knee of patients with severe osteoarthritis has a systemic effect and promotes an anti-inflammatory phenotype of circulating immune cells. Theranostics. 2018;8(20):5519-5528. doi:10.7150/thno. 27674

85. Russo A, Condello V, Madonna V, et al. Autologous and micro-fragmented adipose tissue for the treatment of diffuse degenerative knee osteoarthritis. $J$ Exp Orthop. 2017;4(1):33. doi:10.1186/s40634-017-0108-2

86. Hudetz D, Borić I, Rod E, et al. The effect of intra-articular injection of autologous microfragmented fat tissue on proteoglycan synthesis in patients with knee osteoarthritis. Genes (Basel). 2017;8 (10):270. doi: $10.3390 /$ genes 8100270

87. Fodor PB, Paulseth SG. Adipose derived stromal cell (ADSC) injections for pain management of osteoarthritis in the human knee joint. Aesthet Surg J. 2016;36(2):229-236. doi:10.1093/asj/ sjv135

88. Jo CH, Chai JW, Jeong EC, et al. Intra-articular injection of mesenchymal stem cells for the treatment of osteoarthritis of the knee: a 2 year follow-up study. Am J Sports Med. 2017;45 (12):2774-2783. doi:10.1177/0363546517716641

89. Suzuki K, Sun R, Origuchi M, et al. Mesenchymal stromal cells promote tumor growth through the enhancement of neovascularization. Mol Med. 2011;17:579-587. doi:10.2119/ molmed.2010.00157

90. Toyserkani NM, Jørgensen MG, Tabatabaeifar S, et al. Concise review: a safety assessment of adipose-derived cell therapy in clinical trials: a systematic review of reported adverse events. Stem Cells Transl Med. 2017;6(9):1786-1794. doi:10.1002/ sctm.17-0031

91. Sato M, Uchida K, Nakajima H, et al. Direct transplantation of mesenchymal stem cells into the knee joints of Hartley strain guinea pigs with spontaneous osteoarthritis. Arthritis Res Ther. 2012;14(1):R31. doi:10.1186/ar3735

92. Lamo-Espinosa JM, Mora G, Blanco JF, et al. Intra-articular injection of two different doses of autologous bone marrow mesenchymal stem cells versus hyaluronic acid in the treatment of knee osteoarthritis: multicenter randomized controlled clinical trial (phase I/II). J Transl Med. 2016;14(1):246. doi:10.1186/s12967016-0998-2

93. Pires de Carvalho P, Hamel KM, Duarte R, et al. Comparison of infrapatellar and subcutaneous adipose tissue stromal vascular fraction and stromal/stem cells in osteoarthritic subjects. J Tissue Eng Regen Med. 2014;8(10):757-762. doi:10.1002/term.1565

94. Bourin P, Bunnell BA, Casteilla L, et al. Stromal cells from the adipose tissue-derived stromal vascular fraction and culture expanded adipose tissue-derived stromal/stem cells: a joint statement of the International Federation for Adipose Therapeutics and Science (IFATS) and the International Society for Cellular Therapy (ISCT). Cytotherapy. 2013;15(6):641-648. doi:10.1016/j.jcyt.2013. 02.006

95. Kim YS, Choi YJ, Suh DS, et al. Mesenchymal stem cell implantation in osteoarthritic knees: is fibrin glue effective as a scaffold? Am $J$ Sports Med. 2015;43(1):176-185. doi:10.1177/036354651 4554190

96. Kim YS, Koh YG. Injection of mesenchymal stem cells as a supplementary strategy of marrow stimulation improves cartilage regeneration after lateral sliding calcaneal osteotomy for varus ankle osteoarthritis: clinical and second-look arthroscopic results. Arthroscopy. 2016;32(5):878-889. doi:10.1016/j.arthro.2016.01. 020

97. Kim YS, Kwon OR, Choi YJ, et al. Comparative matched-pair analysis of the injection versus implantation of mesenchymal stem cells for knee osteoarthritis. Am J Sports Med. 2015;43 (11):2738-2746. doi:10.1177/0363546515599632
98. Koh YG, Choi YJ. Infrapatellar fat pad-derived mesenchymal stem cell therapy for knee osteoarthritis. Knee. 2012;19(6):902-907. doi:10.1016/j.knee.2012.04.001

99. Koh YG, Kwon OR, Kim YS, et al. Comparative outcomes of open-wedge high tibial osteotomy with platelet-rich plasma alone or in combination with mesenchymal stem cell treatment: a prospective study. Arthroscopy. 2014;42(7):1453-1460. doi:10. 1016/j.arthro.2014.05.036

100. Koh YG, Choi YJ, Kwon SK, et al. Clinical results and second-look arthroscopic findings after treatment with adipose-derived stem cells for knee osteoarthritis. Knee Surg Sports Traumatol Arthrosc. 2015;23 (5):1308-1316. doi:10.1007/s00167-013-2807-2

101. Koh YG, Kwon OR, Kim YS, et al. Adipose-derived mesenchymal stem cells with microfracture versus microfracture alone: 2-year follow-up of a prospective randomized trial. Arthroscopy. 2016;32 (1):97-109. doi:10.1016/j.arthro.2015.09.010

102. Koh YG, Choi YJ, Kwon OR, et al. Second-look arthroscopic evaluation of cartilage lesions after mesenchymal stem cell implantation in osteoarthritic knees. Am J Sports Med. 2014;42 (7):1628-1637. doi:10.1177/0363546514529641

103. Koh YG, Jo SB, Kwon OR, et al. Mesenchymal stem cell injections improve symptoms of knee osteoarthritis. Arthroscopy. 2013;29 (4):748-755. doi:10.1016/j.arthro.2012.11.017

104. Bui K, Duong TD, Nguyen NT, et al. Symptomatic knee osteoarthritis treatment using autologous adipose derived stem cells and platelet-rich plasma: a clinical study. Biomed Res Ther. 2014;1 (1):2-8. doi:10.15419/bmrat.v1i01.11

105. Pak J, Chang JJ, Lee JH, et al. Safety reporting on implantation of autologous adipose tissue-derived stem cells with platelet-rich plasma into human articular joints. BMC Musculoskelet Disord. 2013;14:337. doi:10.1186/1471-2474-14-337

106. Rehman J, Traktuev D, Li J, et al. Secretion of angiogenic and anti-apoptotic factors by human adipose stromal cells. Circulation. 2004;109(10):1291-1298. doi:10.1161/01.CIR.0000121425.42966.F1

107. Strioga M, Viswanathan S, Darinskas A, et al. Same or not the same? Comparison of adipose tissue-derived versus bone marrow-derived mesenchymal stem and stromal cells. Stem Cells Dev. 2012;21(14):2724-2752. doi:10.1089/scd.2011.0722

108. Cawthorn WP, Scheller EL, MacDougald OA. Adipose tissue stem cells: the great WAT hope. Trends Endocrinol Metab. 2012;23 (6):270-277. doi:10.1016/j.tem.2012.01.003

109. Jo $\mathrm{CH}$, Lee $\mathrm{YG}$, Shin $\mathrm{WH}$, et al. Intra-articular injection of mesenchymal stem cells for the treatment of osteoarthritis of the knee: a proof-of-concept clinical trial. Stem Cells. 2014;32 (5):1254-1266. doi:10.1002/stem.1634

110. Chevalier X, Eymard F, Richette P. Biologic agents in osteoarthritis: hopes and disappointments. Nat Rev Rheumatol. 2013;9 (7):400-410. doi:10.1038/nrrheum.2013.44

111. Kapoor M, Martel-Pelletier J, Lajeunesse D, et al. Role of proinflammatory cytokines in the pathophysiology of osteoarthritis. Nat Rev Rheumatol. 2011;7(1):33-42. doi:10.1038/nrrheum.2010.196

112. Ashraf S, Cha BH, Kim JS, et al. Regulation of senescence associated signaling mechanisms in chondrocytes for cartilage tissue regeneration. Osteoarthritis Cartilage. 2016;24(2):196-205. doi:10.1016/j.joca.2015.07.008

113. Kato T, Miyaki S, Ishitobi $\mathrm{H}$, et al. Exosomes from IL-1 $\beta$ stimulated synovial fibroblasts induce osteoarthritic changes in articular chondrocytes. Arthritis Res Ther. 2014;16(4):R163. doi:10.1186/ar4679

114. Chevalier X, Goupille P, Beaulieu AD, et al. Intraarticular injection of anakinra in osteoarthritis of the knee: a multicenter, randomized, double-blind, placebo-controlled study. Arthritis Rheum. 2009;61 (3):344-352. doi:10.1002/art.24096

115. Stannus O, Jones G, Cicuttini F, et al. Circulating levels of IL-6 and TNF- $\alpha$ are associated with knee radiographic osteoarthritis and knee cartilage loss in older adults. Osteoarthr Cartil. 2010;18 (11):1441-1447. doi:10.1016/j.joca.2010.08.016 
116. Ohtori S, Orita S, Yamauchi K, et al. Efficacy of direct injection of etanercept into knee joints for pain in moderate and severe knee osteoarthritis. Yonsei Med J. 2015;56(5):1379. doi:10.3349/ ymj.2015.56.5.1379

117. Ruan MZ, Cerullo V, Cela R, et al. Treatment of osteoarthritis using a helper-dependent adenoviral vector retargeted to chondrocytes. Mol Ther Methods Clin Dev. 2016;3:16008. doi:10.1038/ mtm. 2016.8

118. Evans CH, Ghivizzani SC, Robbins PD. Gene delivery to joints by intra-articular injection. Hum Gene Ther. 2018;29(1):2-14. doi:10.1089/hum.2017.181

119. Sun SF, Hsu CW, Lin HS, et al. Efficacy of intraarticular botulinum toxin $\mathrm{A}$ and intraarticular hyaluronate plus rehabilitation exercise in patients with unilateral ankle osteoarthritis: a randomized controlled trial. J Foot Ankle Res. 2014;7(1):9. doi:10.1186/17571146-7-9

120. Freund B, Schwartz M. Temporal relationship of muscle weakness and pain reduction in subjects treated with botulinum toxin A. J Pain. 2003;4(3):159-165. doi:10.1054/jpai.2003.435

121. Durham PL, Cady R, Cady R. Regulation of calcitonin gene-related peptide secretion from trigeminal nerve cells by botulinum toxin type A: implications for migraine therapy. Headache. 2004;44 (1):35-42. doi:10.1111/j.1526-4610.2004.04007.x

122. Bao X, Tan JW, Flyzik M, et al. Effect of therapeutic exercise on knee osteoarthritis after intra-articular injection of botulinum toxin type A, hyaluronate or saline: a randomized controlled trial. $J$ Rehabil Med. 2018;50(6):534-541. doi:10.2340/16501977-2340

123. Oo WM, Linklater JM, Hunter DJ. Imaging in knee osteoarthritis. Curr Opin Rheumatol. 2017;29(1):86-95. doi:10.1097/BOR.00 00000000000350
124. Roemer FW, Collins J, Kwoh CK, et al. MRI-based screening for structural definition of eligibility in clinical DMOAD trials: rapid OsteoArthritis MRI Eligibility Score (ROAMES). Osteoarthritis Cartilage. 2020;28(1):71-81. doi:10.1016/j.joca.2019.08.005

125. Rodriguez-Merchan EC. Intra-articular injections of hyaluronic acid and other drugs in the knee joint. HSS J. 2013;9(2):180-182. doi:10.1007/s11420-012-9320-x

126. Bisicchia S, Bernardi G, HYADD TC. 4 versus methylprednisolone acetate in symptomatic knee osteoarthritis: a single-centre single blind prospective randomised controlled clinical study with a 1-year follow-up. Clin Exp Rheumatol. 2016;34(5):857-863.

127. Forogh B, Mianehsaz E, Shoaee S, et al. Effect of single injection of platelet-rich plasma in comparison with corticosteroid on knee osteoarthritis: a double-blind randomized clinical trial. J Sports Med Phys Fitness. 2016;56:901-908.

128. Chang KV, Hung CY, Aliwarga F, et al. Comparative effectiveness of platelet-rich plasma injections for treating knee joint cartilage degenerative pathology: a systematic review and meta-analysis Arch Phys Med Rehabil. 2014;95(3):562-575. doi:10.1016/j. apmr.2013.11.006

129. Vega A, Martín-Ferrero MA, Del Canto F, et al. Treatment of knee osteoarthritis with allogeneic bone marrow mesenchymal stem cells: a randomized controlled trial. Transplantation. 2015;99 (8):1681-1690. doi:10.1097/TP.0000000000000678

130. Hong Z, Chen X, Bi Q, et al. Intra-articular injection of autologous adipose-derived stromal vascular fractions for knee osteoarthritis: a double-blind randomized self-controlled trial. Int Orthop. 2019;43 (5):1123-1134. doi:10.1007/s00264-018-4099-0
Journal of Pain Research

\section{Publish your work in this journal}

The Journal of Pain Research is an international, peer reviewed, open access, online journal that welcomes laboratory and clinical findings in the fields of pain research and the prevention and management of pain. Original research, reviews, symposium reports, hypothesis formation and commentaries are all considered for publication. The manuscript management system is completely online and includes a very quick and fair peer-review system, which is all easy to use. Visit http:// www.dovepress.com/testimonials.php to read real quotes from published authors. 